\title{
The Effect of Mineral and Organic Fertilization on Some Soil Chemical Properties after Perennial Ryegrass Cultivation
}

\author{
Ewa Możdżer ${ }^{1 *}$, Piotr Styrczula ${ }^{2}$ \\ 1 Department of Soil Science, Grassland Mangement and Environmental Chemistry, West Pomeranian University \\ of Technology in Szczecin, ul. Słowackiego 17, 71-434 Szczecin, Poland, e:mail:ewa.mozdzer@zut.edu.pl \\ 2 Factory of Mineral Fertilizers „Fosfan” SA, Szczecin \\ * Corresponding author's e-mail: ewa.mozdzer@zut.edu.pl
}

\begin{abstract}
The three-factorial vegetative-pot experiment was carried out in 2007-2008. The first factor consisted of the series with and without compost of municipal sewage sludge and the second factor involved doses of multi-component mineral fertilizers. Perennial ryegrass (Lolium perenne) of Stadion cv. was the test plant. The purpose of the work was to determine the effect of mineral multi-component fertilizers with combined organic fertilization on the content total and forms assimilable of macroelements in soil. Single doses of mineral fertilizers and urea increased the content of nitrogen, phosphorus and potassium in the soil compared to the control. Doubling the doses of fertilizers and urea raised the content of nitrogen, phosphorus and potassium in the soil as compared to single doses. Types of multicomponent mineral fertilizers with the addition of urea did not have a major impact on the diversity of studied elements content in the soil. After two years of experiment, the soil to which compost was introduced in spring contained more nitrogen and phosphorus compared to the control object by $21 \%$ and $8.96 \%$ respectively. The potassium content in the soil was the same as in the control object. Doubling the doses of mineral fertilizers and urea with the participation of compost resulted in an increase in the content of available forms of phosphorus, potassium, magnesium and sulfate in the soil by $2.52 \%, 9.12 \%, 2.25 \%$ and $0.80 \%$, respectively, in comparison with single doses. The content of available forms of phosphorus and potassium in the soil after the end of the experiment was greater than of the available forms of magnesium and sulfur.
\end{abstract}

Keywords: multi-component mineral fertilizers, compost, soil, content total and available forms of macroelements

\section{INTRODUCTION}

In the last several years, the livestock population has significantly decreased in Poland. As a consequence, a reduction in the production of natural fertilizers occurred. The level of mineral fertilization and the consumption of calcium fertilizers decreased as well. The crop structure was changed. An increased area of cereal crops was recorded. Cereals belong to the plants that negatively affect the balance of organic matter in soils. This led to a reduction in the amount of organic matter and nutrients in the soil environment, the presence of which is essential for the proper growth and development of plants. The search for alternative, cheaper and also environmentally safe sources of organic matter and nutrients for plants has become an important direction. Municipal sewage sludge contains a great amount of organic matter and some nutrients for plants and can be used for fertilizing purposes. The fertilizer value of municipal sewage sludge was positively evaluated in many scientific studies, including: Torri et al. [2009], Roca-Perez et al. [2009], Iżewska [2007, 2009], Krzywy-Gawrońska et al. [2009], Bień et al. [2014], Siebielec et al. [2015].

In addition to the nutrients for plants, municipal sewage sludge may also contain excessive amounts of heavy metals, pathogenic microorganisms, parasites and their live eggs. High variability of chemical composition of municipal sewage sludge, including the content of heavy metals, may limit the possibility of using them for natural purposes. According to the applicable 
legislation in Poland, municipal sewage sludge for agricultural management should comply with the standards regarding the content of heavy metals and microbial contamination contained in the Regulation of the Minister of Environment [Journal of Laws, 2015, item 257]. Before entering the soil, municipal sewage sludge should be stabilized and hygienized.

The aim of the work was to determine the effect of fertilization using multicomponent mineral fertilizers (SuproFoska 20, Suprofos 25 and Inmark 4) in combination with urea and compost produced from municipal sewage sludge on some quality features of the soil after cultivation of perennial ryegrass.

\section{MATERIAL AND RESEARCH METODES}

In order to implement the research goal, a vegetation-pot experiment was set up in the vegetation hall of the West Pomeranian University of Technology. Soil with grain composition of strong loamy sand, included in the rye complex of very good bonitation class IVa, was used for the research. The soil was delivered from the Agricultural Experimental Station in Lipnik near Stargard.

The soil samples for chemical analyzes were collected from the top layer $(0-20 \mathrm{~cm})$ three times: before planting, after the third cut of ryegrass in the first year of experiment and after completing the experiment. The soil used for the study was almost neutral. The content of available forms of phosphorus, potassium and magnesium was medium and sulfate - low (Table 1). Due to the fact that the compost from municipal sewage sludge was used in the experiment, the total content of heavy metals was also determined in the soil. The chemical analysis indicated that the total content of heavy metals did not exceed the permissible standards that were specified in the ministerial regulations [Journal of Laws, 2015, item 257] for using the municipal sewage sludge. The dose of mineral fertilizers (SuproFoska 20, Suprofos 25 and Inmark 4) was set at $200 \mathrm{~kg} \cdot \mathrm{ha}^{-1}$ (single dose) and $400 \mathrm{~kg} \cdot \mathrm{ha}^{-1}$ (doubled dose). The fertilizers were applied in the amounts: $0.6 \mathrm{~g}$ (dose I) and $1.2 \mathrm{~g}$ (dose II). Due to the low content of nitrogen in multicomponent mineral fertilizers, this element was introduced in the form of urea.

The average soil samples were subjected to the following determinations: dry mass by drying method - according to PN-75C-04616/01; $\mathrm{pH}$ in $1 \mathrm{M} \mathrm{KCl}$ potentiometrically - PN-ISO 10390; total phosphorus - Barton's colorimetric method; potassium and total calcium - flame spectrometry; total magnesium - atomic absorption spectrometry (AAS) after mineralization in a mixture of nitric(V) acid and perchloric(VII) acid at 1:1 ratio; nitrogen, carbon and sulfur were analyzed in an elemental analyzer of the Vario Max type (CNS), sulfate - nephelometric method; available phosphorus and potassium - according to PN-R-04022/Az1, available magnesium - according to PN-R-04020/Az1.

The experiment was carried out in a complete randomization system with separation of the control group. The statistical calculations on the significance of differences in macronutrient content in the soil were performed using a two-factor variance analysis for the split-block system according to the FR-ANALWAR software. The confidence half-intervals were determined for $\mathrm{p}=0.05$, applying the Tukey's test.

\section{RESULTS AND DISCUSSION}

At the end of the experiment, the $\mathrm{pH}_{\mathrm{KCl}}$ value of the control soil did not change from the initial value (prior to the experiment establishing). Single doses of multicomponent mineral fertilizers and urea decreased the $\mathrm{pH}_{\mathrm{KCl}}$ value of soil by 0.1 unit, in relation to the control object (Table 2). Under the influence of double doses of mineral fertilizers and urea, the $\mathrm{pH}_{\mathrm{KCl}}$ value of soil decreased by 0.2 units in relation to that before the experiment and to the control. Introduction of compost from municipal sewage sludge to the soil increased its $\mathrm{pH}_{\mathrm{KCl}}$ value in relation to the control object (Tables 2 and 3). It was associated with the $\mathrm{pH}$ value of compost and the neutralizing effect of the organic substance from compost on acidification

Table 1. Some indicators of soil fertility used in the vegetation-pot experiment

\begin{tabular}{|c|c|c|c|c|c|c|c|c|c|c|c|c|}
\hline \multirow{2}{*}{$\mathrm{pH}_{\mathrm{KCL}}$} & \multicolumn{7}{|c|}{ Total content $\left(\mathrm{g} \cdot \mathrm{kg}^{-1} \mathrm{~d} . \mathrm{m}.\right)$} & \multirow{2}{*}{$\mathrm{C}: \mathrm{N}$} & \multicolumn{4}{|c|}{ Available forms $\left(\mathrm{mg} \cdot \mathrm{kg}^{-1} \mathrm{~d} . \mathrm{m}.\right)$} \\
\hline & C org. & $\mathrm{N}$ & $P$ & $\mathrm{~K}$ & $\mathrm{Ca}$ & $\mathrm{Mg}$ & $S$ & & $\mathrm{P}$ & $\mathrm{K}$ & $\mathrm{Mg}$ & $\mathrm{S}-\mathrm{SO}_{4}$ \\
\hline 6.5 & 12.2 & 1.05 & 1.53 & 2.85 & 4.51 & 0.46 & 2.50 & 11.6 & 64.5 & 123.0 & 48.4 & 12.5 \\
\hline
\end{tabular}


of soil material. This thesis is confirmed by the results from the use of multicomponent mineral fertilizers and urea with the participation of compost. The value of $\mathrm{pH}_{\mathrm{KCl}}$ in the soil in this series of experiments using single doses of multicomponent mineral fertilizers and urea did not change compared to the control and the result obtained before the experiment, while it slightly decreased (except for the object with Suprofosem 25) after using double doses of mineral fertilizers. The stabilizing effect of the composts from municipal sewage sludge on soil reaction was confirmed by Krzywy et al. [2002], Patorczyk-Pytlik [2001], Pisarek [2000], Stępnia et al. [2001], Wołoszyka [2003], Możdżer and Chudecka [2017].

The differences in the effect of mineral fertilizers and urea both in a single and double dose used without and with the participation of compost on the $\mathrm{pH}_{\mathrm{KCl}}$ value in the soil were negligible. Nowak and Draszawka-Bołzan [2002] and Jasiewicz et al. [2007] reported that mineral fertilizers cause acidification of soils. The obtained results indicate that the multicomponent mineral fertilizers used in the experiment had a small influence on the reduction in $\mathrm{pH}_{\mathrm{KCl}}$ of soil after a two-year study period.

The organic carbon content in the soil after the two-year study period decreased by $5.17 \%$ compared to the control object (Tables 1 and 2). Mineral fertilizers and urea used in single and double doses slightly increased the organic carbon content in the soil compared to the result before the experiment was established. The organic carbon content ranged from 12.3 to $12.5 \mathrm{~g} \mathrm{C}_{\text {org }} \cdot \mathrm{kg}^{-1} \mathrm{~d} . \mathrm{m}$. While comparing the obtained results with the control, it was found that the mineral fertilizers and urea increased the organic carbon content in the soil by $6.89 \%$. The differences in the effect of individual mineral fertilizers used in single and double doses on the organic carbon content in the soil were small. The compost introduced into the soil increased the organic carbon content by $7.80 \%$ compared to the control (Tables 2 and 3 ). The differences in the action of individual mineral fertilizers applied along with compost on the content of organic carbon in the soil were negligible. The results of the research indicate the bi-directional effect of mineral and organic fertilizers. The increase of the organic carbon content in the soil occurred on one hand under the influence of fertilizers, as a result of which the mass of roots of the test plant increased, while on the other hand, under the influence of compost enriching the soil material with an organic substance. A slight increase in the organic carbon content in soil after the use of compost was confirmed by the studies of Kopcia et al. [2000], Krzywy-Gawrońska [2006, 2009], Siuta et al. [2007].

The interaction of mineral and organic fertilizers, according to Bednarek et al. [2004] and Maciejewskiej [1998] consists in increasing the fertility of soils. One of the main indicators of soil fertility is the content of nutrients for plants [Krzywy et al. 2008, Siuta et al. 2007]. Total content of nitrogen, phosphorus and potassium in the soil of the control object was smaller than before the experiment. Single doses of mineral fertilizers and urea increased the content of nitrogen, phosphorus and potassium in the soil compared to the control. The differences in comparison to the results from before the experiment were not significant. Doubling the doses of fertilizers and urea increased the content of nitrogen, phosphorus and potassium in the soil as compared to single doses.

Table 2. Total content of macroelements and $\mathrm{pH}$ of the soil after completion of the experiment on the objects without compost (average of two years) $\left(\mathrm{g} \cdot \mathrm{kg}^{-1} \mathrm{~d} . \mathrm{m}\right.$.)

\begin{tabular}{|c|c|c|c|c|c|c|c|c|c|c|c|}
\hline \multirow{5}{*}{ Specyfication } & \multirow{5}{*}{ Control } & \multirow{5}{*}{$\begin{array}{l}\mathrm{LSD}_{0,05} \text { for: } \\
\text { dose } \\
\text { fertilisation }\end{array}$} & \multicolumn{9}{|c|}{ Fertilisation objects } \\
\hline & & & \multicolumn{9}{|c|}{ without compost } \\
\hline & & & \multicolumn{3}{|c|}{ SuproFoska 20} & \multicolumn{3}{|c|}{ Suprofos 25} & \multicolumn{3}{|c|}{ Inmarc 4} \\
\hline & & & \multicolumn{9}{|c|}{+ urea } \\
\hline & & & dose I & dose II & mean & dose I & dose II & mean & dose I & dose II & mean \\
\hline $\mathrm{pH}_{\mathrm{KCl}}$ & 6.5 & n.i. & 6.4 & 6.3 & - & 6.4 & 6.3 & - & 6.3 & 6.4 & - \\
\hline C org. & 11.6 & 0.14 & 12.3 & 12.4 & 12.3 & 12.4 & 12.5 & 12.5 & 12.3 & 12.4 & 12.3 \\
\hline$N$ & 0.95 & 0.08 & 1.08 & 1.12 & 1.10 & 1.07 & 1.13 & 1.10 & 1.08 & 1.13 & 1.10 \\
\hline$P$ & 1.45 & n.s. & 1.54 & 1.57 & 1.56 & 1.55 & 1.58 & 1.57 & 1.54 & 1.56 & 1.55 \\
\hline $\mathrm{K}$ & 2.78 & n.s. & 2.85 & 2.89 & 2.87 & 2.85 & 2.90 & 2.87 & 2.85 & 2.88 & 2.86 \\
\hline $\mathrm{Ca}$ & 4.45 & n.s. & 4.46 & 4.47 & 4.46 & 4.45 & 4.48 & 4.46 & 4.46 & 4.47 & 4.46 \\
\hline $\mathrm{Mg}$ & 0.44 & n.s. & 0.46 & 0.47 & 0.46 & 0.47 & 0.48 & 0.47 & 0.47 & 0.46 & 0.46 \\
\hline$S$ & 2.35 & n.s. & 2.37 & 2.39 & 2.38 & 2.38 & 2.40 & 2.39 & 2.38 & 2.40 & 2.39 \\
\hline
\end{tabular}


Table 3. Total content of macroelements and $\mathrm{pH}$ of the soil after completion of the experiment on the objects with compost (average of two years) $\left(\mathrm{g} \cdot \mathrm{kg}^{-1} \mathrm{~d} . \mathrm{m}\right.$.)

\begin{tabular}{|c|c|c|c|c|c|c|c|c|c|c|c|}
\hline \multirow{5}{*}{ Specyfication } & \multirow{5}{*}{ Compost } & \multirow{5}{*}{$\begin{array}{l}\mathrm{LSD}_{0,05} \text { for: } \\
\text { dose } \\
\text { fertilisation }\end{array}$} & \multicolumn{9}{|c|}{ Fertilisation objects } \\
\hline & & & \multicolumn{9}{|c|}{ with compost } \\
\hline & & & \multicolumn{3}{|c|}{ SuproFoska 20} & \multicolumn{3}{|c|}{ Suprofos 25} & \multicolumn{3}{|c|}{ Inmarc 4} \\
\hline & & & \multicolumn{9}{|c|}{+ urea } \\
\hline & & & dose I & dose II & mean & dose I & dose II & mean & dose I & dose II & mean \\
\hline $\mathrm{pH}_{\mathrm{KCl}}$ & 6.6 & n.s. & 6.5 & 6.4 & - & 6.5 & 6.5 & - & 6.5 & 6.4 & - \\
\hline C org. & 12.5 & 0.11 & 12.6 & 12.8 & 12.7 & 12.6 & 12.8 & 12.7 & 12.6 & 12.9 & 12.8 \\
\hline $\mathrm{N}$ & 1.15 & n.s. & 1.20 & 1.25 & 1.22 & 1.22 & 1.26 & 1.24 & 1.21 & 1.25 & 1.23 \\
\hline $\mathrm{P}$ & 1.58 & n.s. & 1.59 & 1.61 & 1.60 & 1.60 & 1.62 & 1.61 & 1.59 & 1.61 & 1.60 \\
\hline K & 2.78 & 0.09 & 2.85 & 2.88 & 2.86 & 2.86 & 2.89 & 2.88 & 2.84 & 2.88 & 2.86 \\
\hline $\mathrm{Ca}$ & 4.52 & n.s. & 4.52 & 4.54 & 4.53 & 4.53 & 4.55 & 4.54 & 4.54 & 4.56 & 4.55 \\
\hline $\mathrm{Mg}$ & 0.47 & n.s. & 0.48 & 0.48 & 0.48 & 0.49 & 0.49 & 0.49 & 0.47 & 0.48 & 0.48 \\
\hline $\mathrm{S}$ & 2.50 & n.s. & 2.52 & 2.54 & 2.53 & 2.52 & 2.55 & 2.53 & 2.51 & 2.54 & 2.52 \\
\hline
\end{tabular}

The types of multicomponent mineral fertilizers with the addition of urea did not have a major impact on the diversity of studied elements content in the soil. After two years of experiment, the soil to which compost was introduced in spring contained more nitrogen and phosphorus compared to the control object by $21 \%$ and $8.96 \%$, respectively (Table 3 ). The potassium content in the soil was the same as in the control object and lesser by $2.51 \%$ than before the experiment.

Single and double doses of mineral fertilizers and urea applied with the use of compost increased the total content of nitrogen, phosphorus and potassium in the soil in comparison to the object, where only organic fertilizer was used. The differences in the effect of individual mineral fertilizers and urea on the content of these macronutrients were not significant (Tables 2, 3).

The total content of calcium, magnesium and sulfur in the soil of control object was smaller than before the experiment. Mineral fertilizers and urea applied without and with the use of compost did not have a major impact on the diversity of calcium and magnesium content in the soil. The total sulfur content slightly increased compared to the control under the influence of the applied compost. Mineral fertilizers and urea applied with compost did not have a major impact on the sulfur content in the soil.

In the objects where compost was used, the total content of nitrogen, phosphorus, calcium, magnesium and sulfur in the soil was higher than that obtained in the series of experiments with mineral fertilizers (Tables 2, 3). This confirms the thesis about the beneficial interaction of mineral fertilizers with organic fertilizers (compost) in increasing the soil fertility. The content of potassium in the soil of control with compost was lower than that before the experiment. The content of potassium in a series of experiments, in which mineral fertilizers were used, including compost, was not much different from that obtained in the experimental series only with mineral fertilization. The obtained results prove that the applied compost is characterized by low content of potassium in relation to nitrogen and phosphorus. Similar conclusions were made by Baran et al. [2009], Siuta et al. [2007], Wołoszyk et al. [2016], KrzywyGawrońska [2013], Strączyńska [1998].

The content of available forms of phosphorus, potassium, magnesium and sulfate in the soil of the control object was smaller than before the experiment (Tables 1 and 4). Single doses of mineral fertilizers and urea increased the content of available forms for: phosphorus in the range of 5.5 to $6.2 \mathrm{mg} \mathrm{P} \cdot \mathrm{kg}^{-1} \mathrm{~d} . \mathrm{m}$. (Figure 1) and potassium from 5.1 to $7.0 \mathrm{mg} \mathrm{K} \cdot \mathrm{kg}^{-1} \mathrm{~d} . \mathrm{m}$. (Figure 2), compared to the control. The content of bioavailable forms for magnesium and sulfate in the soil slightly increased in relation to the control object. The content of available form of magnesium increased from 0.6 to $1.1 \mathrm{mg} \mathrm{Mg} \cdot \mathrm{kg}^{-1} \mathrm{~d}$.m. (Figure 3), while sulfate from 0.1 to $0.2 \mathrm{mg} \mathrm{S}-\mathrm{SO}_{4} \cdot \mathrm{kg}^{-1}$ d.m. of soil.

Doubling the doses of mineral fertilizers and urea increased the content of available forms of: phosphorus, potassium, magnesium and sulfate by $2.91 \%, 6.49 \%, 1.92 \%$ and $1.62 \%$, respectively, in comparison to single doses. The compost introduced into the soil contributed to the increase in the content of phosphorus, potassium, magnesium and sulfate forms in comparison to the control object (Table 4 and Figures 1, 2, 3).

Single doses of mineral fertilizers with the addition of urea applied with the use of compost 


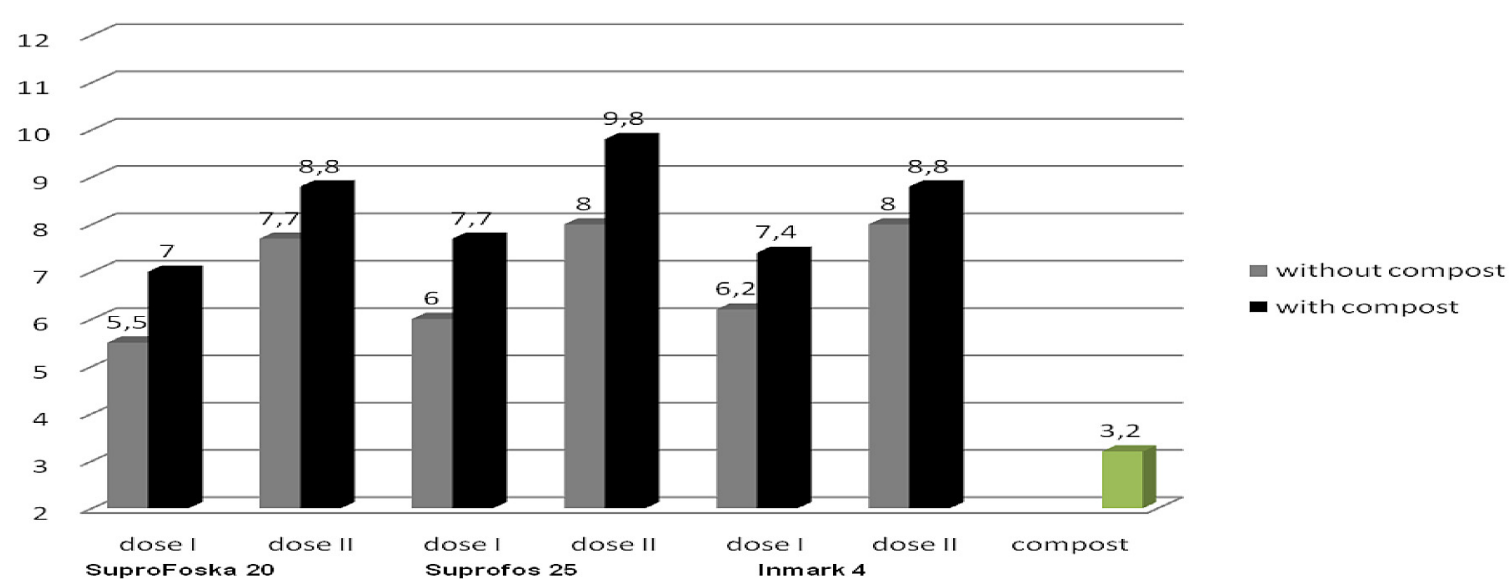

Figure 1. Increasing the content of available form of phosphorus in the soil compared to the control object, obtained under the influence of single and double doses of mineral fertilizers with and without the participation of compost

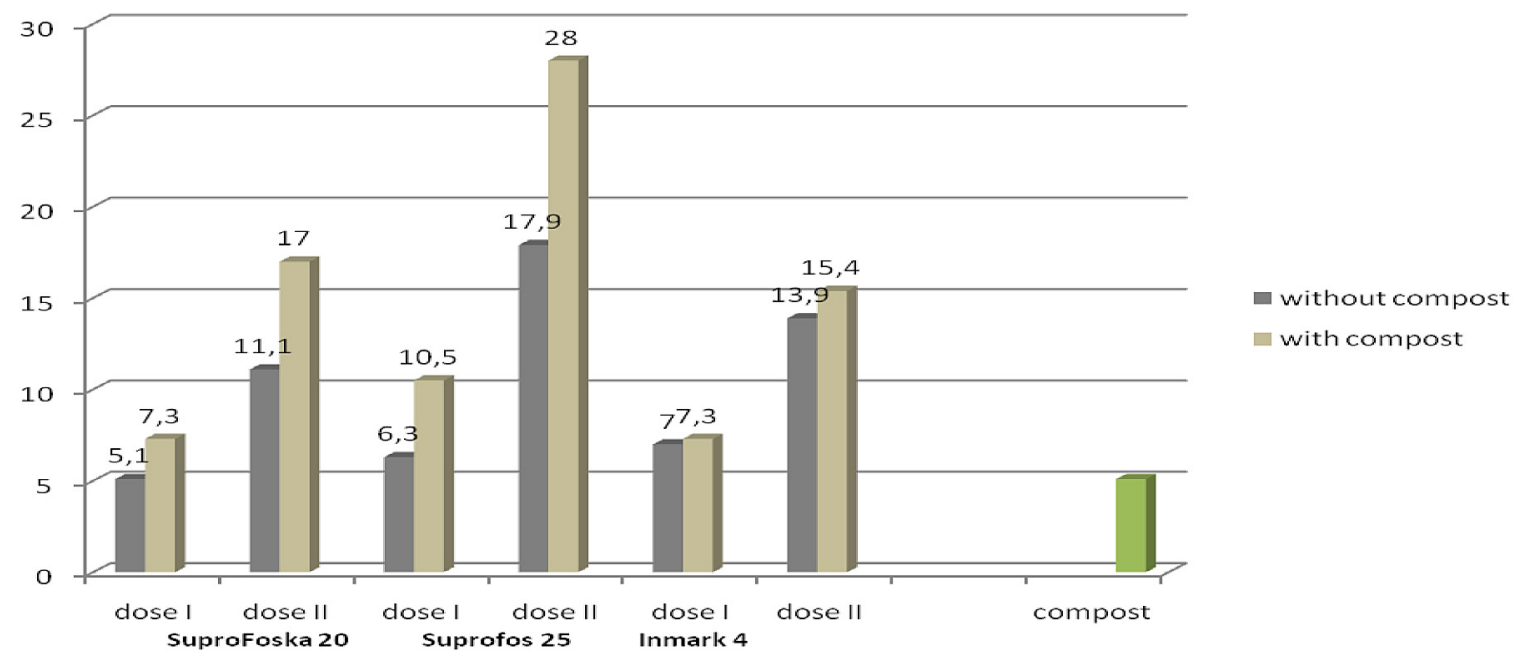

Figure 2. Increasing the content of available form of potassium in the soil compared to the control object, obtained under the influence of single and double doses of mineral fertilizers with and without the participation of compost

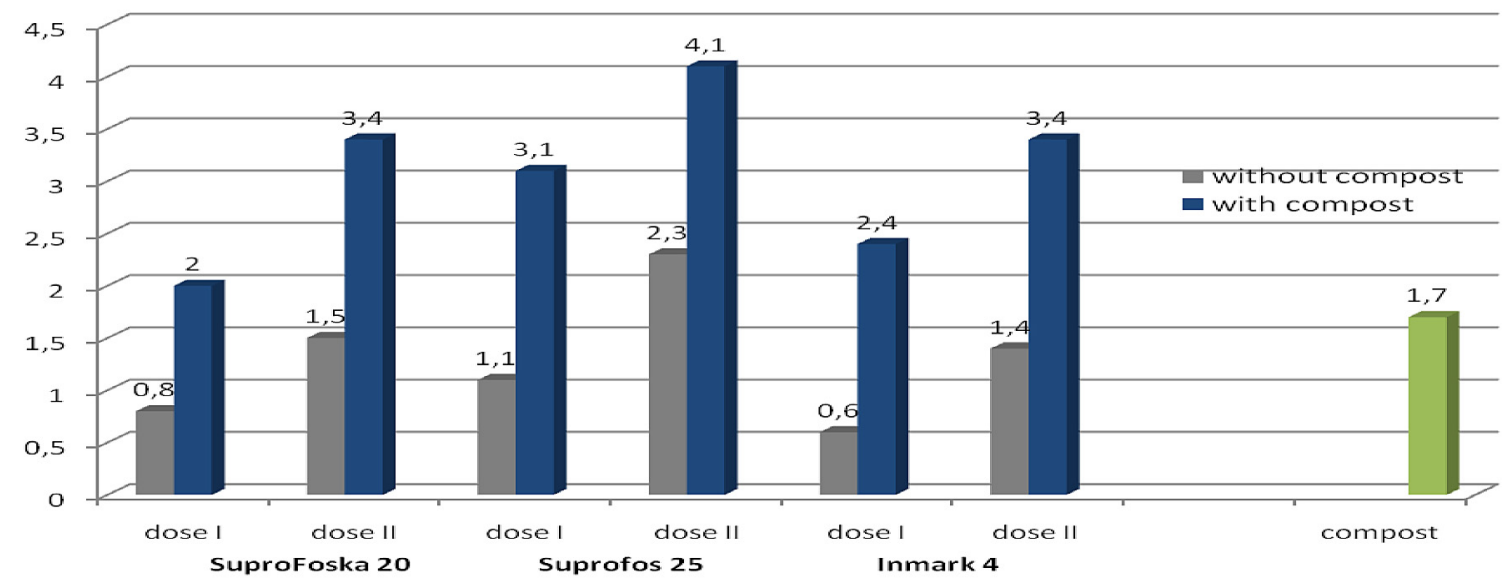

Figure 3. Increasing the content of available form of magnesium in the soil compared to the control object, obtained under the influence of single and double doses of mineral fertilizers with and without the participation of compost 
Table 4. Average content of available forms of phosphorus, potassium, magnesium and sulfur in the soil after the end of the experiment (average of two years) $\left(\mathrm{g} \cdot \mathrm{kg}^{-1} \mathrm{~d} . \mathrm{m}\right.$.)

\begin{tabular}{|c|c|c|c|c|c|c|c|c|c|c|c|c|c|c|}
\hline \multirow{5}{*}{ Specyfication } & \multicolumn{14}{|c|}{ Fertilisation objects } \\
\hline & \multirow{4}{*}{ Control } & \multicolumn{6}{|c|}{ without compost } & \multirow{4}{*}{ Compost } & \multicolumn{6}{|c|}{ with compost } \\
\hline & & \multicolumn{2}{|c|}{ SuproFoska 20} & \multicolumn{2}{|c|}{ Suprofos 25} & \multicolumn{2}{|c|}{ Inmarc 4} & & \multicolumn{2}{|c|}{ SuproFoska 20} & \multicolumn{2}{|c|}{ Suprofos 25} & \multicolumn{2}{|c|}{ Inmarc 4} \\
\hline & & \multicolumn{6}{|c|}{ + urea } & & \multicolumn{6}{|c|}{+ urea } \\
\hline & & dose I & dose II & dose I & dose II & dose I & dose II & & dose I & dose II & dose I & dose II & dose I & $\begin{array}{c}\text { dose } \\
\text { II }\end{array}$ \\
\hline $\mathrm{P}$ & 62.8 & 68.3 & 70.5 & 68.8 & 70.8 & 69.0 & 70.8 & 66.0 & 69.8 & 71.6 & 70.5 & 72.6 & 70.2 & 71.6 \\
\hline $\mathrm{K}$ & 120.2 & 125.3 & 131.3 & 126.5 & 138.1 & 127.2 & 134.1 & 125.3 & 127.5 & 137.2 & 130.7 & 148.2 & 127.5 & 135.6 \\
\hline $\mathrm{Mg}$ & 47.8 & 48.6 & 49.3 & 48.9 & 50.1 & 48.4 & 49.2 & 49.5 & 49.8 & 51.2 & 50.9 & 51.9 & 50.2 & 51.2 \\
\hline $\mathrm{S}-\mathrm{SO}_{4}$ & 12.2 & 12.3 & 12.5 & 12.4 & 12.6 & 12.3 & 12.4 & 12.8 & 12.8 & 12.9 & 12.9 & 13.0 & 12.8 & 12.9 \\
\hline
\end{tabular}

influenced the increase in the content of the following available forms: phosphorus in the range from 1.2 to $1.7 \mathrm{mg} \mathrm{P} \cdot \mathrm{kg}^{-1} \mathrm{~d}$.m., potassium from 0.3 to $4.2 \mathrm{mg} \mathrm{K} \cdot \mathrm{kg}^{-1} \mathrm{~d} . \mathrm{m}$., and magnesium between 1.2 and $2.0 \mathrm{mg} \mathrm{Mg} \cdot \mathrm{kg}^{-1}$ d.m. compared to the objects, where the organic fertilizer was not used. The content of sulfate in the soil after applying single doses of mineral fertilizers and urea with the participation of compost increased only by $0.5 \mathrm{mg} \mathrm{S}-\mathrm{SO}_{4} \cdot \mathrm{kg}^{-1}$ d.m. compared to the objects, in which organic fertilizer was not applied (Table 4 and Figures 1, 2, 3).

Doubling the doses of mineral fertilizers and urea with the participation of compost resulted in an increase in the content of available forms of phosphorus, potassium, magnesium and sulfate in the soil by $2.52 \%, 9.12 \%, 2.25 \%$ and $0.80 \%$, respectively, in comparison with single doses. The content of available forms of phosphorus and potassium in the soil after the end of the experiment was greater than the available forms of magnesium and sulfur. These results are related to the amount of phosphorus, potassium, magnesium and sulfur introduced into the soil in the form of multicomponent mineral fertilizers and compost.

The highest content of available forms of phosphorus, potassium, magnesium and sulfate was obtained on the object with Suprofos 25, whereas the smallest one was obtained on the object with SuproFoska 20. Meanwhile, the lowest level of sulfate in the soil was recorded on the object with Inmark 4. The differences between these objects were slight.

Taking into account the obtained results, in order to increase the yield of perennial ryegrass without fear of lowering its quality and to improve the abundance of soil in nutrients, the following solutions can be recommended:

- increasing the dose of compost produced from municipal sewage sludge. This dose can be increased in terms of nitrogen up to $150 \mathrm{~kg} \mathrm{~N} \cdot \mathrm{ha}^{-1}$,

- increasing the doses of multicomponent mineral fertilizers: Suprofos 25, SuproFoska 20 and Inmark 4 to $600 \mathrm{~kg}$ of fertilizer ha ${ }^{-1}$, with a simultaneous increase in the amount of urea.

Increasing the doses of multicomponent mineral fertilizers, urea and compost should be correlated with the agro-ecological conditions of a given farm, the soil abundance in organic matter and nutrients for plants as well as expected yields of a given plant species and their quality.

\section{CONCLUSIONS}

1. Multicomponent mineral fertilizers and urea used with and without the participation of compost contributed to a decrease in the $\mathrm{pH}_{\mathrm{KCl}}$ value and a slight increase in the organic carbon content and the total content of macroelements in the soil.

2. The applied multicomponent mineral fertilizers and urea used with and without the participation of compost influenced the increase of the content of available forms of phosphorus and potassium in the soil.

3. The study indicates that the content of available form of magnesium and sulfur in the soil under the influence of the applied multicomponent mineral fertilizers and urea increased only to a small extent.

\section{REFERENCE}

1. Baran S., Wójcikowska - Kapusta A., Żukowska G., Bik M., 2009. Changes in the content of phosphorus, potassium and magnesium in composts of various maturity.Zmiany zawartości fosforu, potasu 
i magnezu w kompostach o różnej dojrzałości. Zesz. Probl. Post. Nauk Rol. 537: 25 - 31. [In Polish]

2. Bednarek R., Dziadowiec H., Pokojska U., Prusinkiewicz Z., 2004. Ecological and soil research. PWN Warszawa: 115 - 153. [In Polish]

3. Bień J., Górecki M., Kacprzyk M., Kamizela T., Kowalczyk M., Neczaj E., Pająk T., Wystalska K., 2014. Expertise, which will be the basis material for developing a strategy for dealing with municipal sewage sludge for years 2014-2020. Wyd. Politechnika Częstochowska, 8-107. [In Polish]

4. Iżewska A., 2007. Effect of fertilization with manure, sewage sludge and compost from sewage sludge on soil properties. Zesz. Prob. Post. Nauk Rol. 518:85-92. [In Polish]

5. Iżewska A., 2009. The usefulness of composts from municipal sewage sludge for the fertilization of sugar miscanthus (Miscanthus sacxchariflorus (Maxim.) Hack) Monografia Wyd. ZUT. ss.102. [In Polish]

6. Jasiewicz Cz., Antoniewicz J., Mazur Z., Krajewski W., 2007. Agrochemical properaties of soil fertilized with sewage sludge from sewage treatment plant At Olecko. Ecol. Chem. Eng. 14 (5-6): 457-463. [In Polish]

7. Kopeć M., Mazur K., Gondek K., 2000. The effect of mountain meadow fertilization with waste and tannery sewage sludge and their composts on changes in the value of carbon and nitrogen in soil. Folia Univ. Agric. Stetin. Agricultura 211(84): 167 - 174. [In Polish]

8. Krzywy E., Wołoszyk Cz., Iżewska A., Krzywy J., 2002. Research on the possibility of using municipal sewage sludge with the addition of various components for the production of composts. Acta Agrophysica 70(I): 217 - 223. [In Polish]

9. Krzywy E., Wołoszyk C., Iżewska A., Krzywy Gawrońska E., 2008. Assessment of chemical composition and fertilizing value of municipal sewage sludge and composts in chich they are included. Zesz. Prob. Post. Nauk Rol. 533: 239 - 247. [In Polish]

10. Krzywy-Gawrońska E., 2006. Dynamics of changes in physical and chemical properties of composts and their impact on soil fertility as well as on the size and quality of permanent ryegrass field. Rozprawa doktorska AR w Szczecinie:137. [In Polish]

11. Krzywy-Gawrońska E., 2009. Research on the impact of compost from municipal sewage sludge and active substance PRP Sol on fertility and soil fertility. Monografia, Wyd. ZUT:27-34. [In Polish]

12. Krzywy-Gawrońska E., 2013. Effect of combustion wastes and sewage sludge compost on the chemical properties of soil. Polish Journal of Chemical Technology, 15 (3): 48 - 54. [In Polish]

13. Maciejewska A., 1998. Brown coal as a source of organic matter and its impact on soil properties. Oficyna Wyd. Polit. Warszawska, Warszawa: 5-43.
14. Możdżer E., Chudecka J., 2017. Impact of the natural fertilization using PRP FIX on some soil fertility indicators. Journal of Ecological Engineering 18(4):137-144. [In Polish]

15. Nowak W., Draszawka-Bołzan B., 2002. The content of cadmium, lead and nickel in the perennial ryegrass under the influence of fertilization with multicomponent fertilizers. Zesz. Prob. Post. Nauk Rol., 484: 433 - 439. [In Polish]

16. Patorczyk-Pytlik B., 2001. Agrochemical evaluation of various methods of preparing composts from sewage sludge. Zesz. Nauk AR Wrocław. Rozpr. 401 (1785):104. [In Polish]

17. Pisarek I., 2000. Effect of fertilization with sewage sludge on the concentration of heavy metals and some chemical parameters in the soil. Folia Univ. Agric. Stetin. 223 Agricultura 200 (77): 311-316. [In Polish]

18. Siuta J., Dusik L., Lis W., 2007. Composting of sewage sludge in Sierpcu. Inżynieria Ekologiczna nr 19. [In Polish]

19. Stępień W., Mercik S., 2001. Effect on plants and soil of multicomponent and individual fertilizers in five-field rotation. Folia Univ. Agric. Stetin. 223 Agricultura (89):165-168. [In Polish]

20. Strączyńska S. 1998. Effect of organic and mineral fertilization on the fraction composition of humus compounds and chemical properties of soil. Fol. Univ. Agric. Stein. 190 Agricultura (72): 289-293. [In Polish]

21. Roca-Perez L., Martinez C., Marcilla P., Boluda R., 2009. Composting rice straw with sewage sludge and compost effects on the soil-plant system. Chemosphere (12):58-65.

22. Rozporządzenie Ministra Środowiska $\mathrm{z}$ dnia 6 lutego 2015 r. w sprawie komunalnych osadów ściekowych (Dz. U. 2015., poz. 257).

23. Rozporządzenie Ministra Środowiska z dnia 13 lipca $2010 \mathrm{w}$ sprawie komunalnych osadów ściekowych (Dz.U. 01.137.924).

24. Siebielec S., Urbaniak M., Siebielec G., 2015. Pollutants and methods of treatment of municipal sewage sludge. Studia i Raporty IUNG-PIB, 46(20):47-48. [In Polish]

25. Torri, S. Zubillaga, M., Cusato M., 2009. Potential of discaria americana for metal stabilization on soils amended with biosolids and ash-spiked biosolids. International Journal of Phytoremediation, 11(2):187-199.

26. Wołoszyk C., 2003. Agrochemical evaluation of fertilization with composts from municipal sewage sludge and industrial waste. Rozprawa habilitacyjna 217. Wyd. AR w Szczecinie. ss 120. [In Polish]

27. Wołoszyk C., Możdżer E., Krzywy E., 2016. Evaluation of crop and chemical composition of Winter and spring wheat as well as fertibility of liquid manure-fertilized soil. Przemysł Chemiczny 95(11):2234-2238. [In Polish] 